
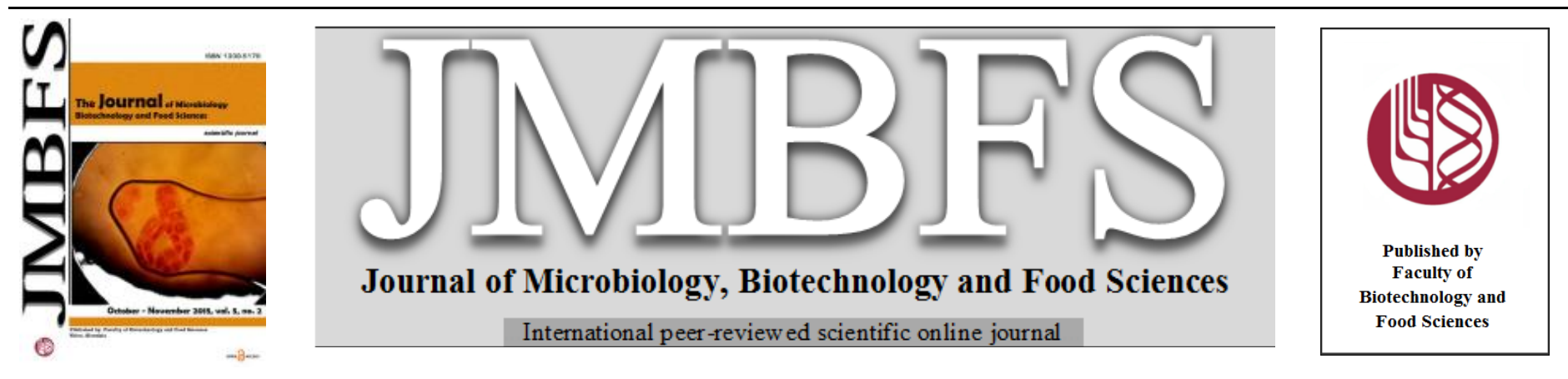

\title{
GENUS SALVIA - ECOSYSTEM FOR ISOLATION OF LACTIC ACID BACTERIA
}

\section{Tsvetanka Teneva-Angelova, Dora Beshkova*}

Address(es):

The Stephan Angeloff Institute of Microbiology-BAS, 26 “Georgi Bonchev” St., 1113 Sofia, Bulgaria, Phone: +35932642430.

*Corresponding author: beshkova@yahoo.com

doi: 10.15414/jmbfs.2015.5.2.103-108

\section{ARTICLE INFO}

Received 16. 12. 2014

Revised 11. 6. 2015

Accepted 22. 6. 2015

Published 1. 10. 2015

Regular article open $\bigodot_{\text {ACCESS }}$

\begin{abstract}
In recent years there has been a trend of increased interest in lactic acid bacteria (LAB) isolated from non-dairy sources due to their diverse metabolic profile and unique flavor-forming activities. This study presents the possibility of using microbial diversity of individual plant parts (flower, leaf and steam) of each species of the genus Salvia for isolation of LAB with new metabolic activities, suitable for their potential inclusion in starter cultures. After screening 800 microbial isolates derived from five species of the genus Salvia and subsequent multiple transfer and growth in selective media, 460 single bacterial colonies were isolated. The data from the required and confirmatory tests established that 56 single colonies showed phenotypic identity (Gram-positive, catalase-negative, oxidase-negative and indole-negative) with the group of LAB. All were classified as homofermentative cocci. $82.2 \%$ of the plantderived lactobacteria synthesized $\mathrm{L}(+)$-lactic acid, but a minor part (11.8\%) synthesized both isomeric forms of lactic acid. Almost all isolates have a wide $\mathrm{pH}$ and temperature range as well as high halotolerance. Using genotype-based methods such as 16S rDNA sequencing, the plant-derived bacterial isolates were identified as: Enterococcus faecium, Enterococcus casseliflavus, Enterococcus mundtii, Lactococcus lactis subsp. lactis and Streptococcus thermophilus.
\end{abstract}

Keywords: Lactic acid bacteria, Genus Salvia, Isolation, 16S rDNA

\section{INTRODUCTION}

Lactic acid bacteria (LAB) include a wide variety of cell types and physiological and biochemical characteristics. They are predominantly represented as a nontaxonomic heterogeneous group of Gram-positive and non-spore forming facultative anaerobic bacteria. LAB could be isolated from traditional sources raw milk, dairy products and fermented foods (Kimoto et al., 2004; Tamang et al., 2005; Nomura et al., 2006; Kostinek et al., 2007; Tanasupawat et al., 2007; Venturi et al., 2012; Abegaz, 2014; Gad et al., 2014; Guley et al., 2014/15) or from alternative sources - fecal samples, soils and plants (Hartnett et al., 2002; Magnusson et al., 2003; Cock and De Stouvenel, 2006; Siezen et al., 2008; Trias et al., 2008; Di Cagno et al., 2009 ; Cakir, 2010; Chen et al., 2010; Venugopalan et al., 2010; Baradaran et al., 2012; Emerenini et al., 2013; Fhoula et al., 2013; Nguyen et al., 2013; Alemayehu et al., 2014). In recent years there has been a trend of increased interest in LAB isolated from non-dairy sources (plant origin) due to their diverse metabolic profile and unique flavor-forming activities. Plant-derived strains of lactobacteria have demonstrated tolerance to high $\mathrm{pH}$ values and salt concentrations, ability to ferment various types of carbohydrates and a high level of stress resistance compared to those of dairy origin. Furthermore, no significant differences were noted in the fermentation characteristics and profiles of enzymes, such as lipases, peptidases and phosphatases, required for obtaining various fermented dairy products with plant-derived and commercial strains of lactobacteria (Nomura et al., 2006; Michaylova et al., 2007; Siezen et al., 2008; Venugopalan et al., 2010).

The search for new solutions to improve health fermented food starters and to expand the opportunities for comprehensive use of the biological potential of LAB has provoked the idea to exploit the unique biodiversity in natural systems (medicinal plants). They are an important ecosystem for isolation of LAB (Siezen et al., 2008; Cakir, 2010; Venugopalan et al., 2010; Baradaran et al., 2012). Each specific plant species provides a unique environment in terms of competing microorganisms, natural plant antagonists, as well as accessibility, type and concentration of the substrate in the various physical factors. These conditions allow for the growth of typical epiphytic flora, which gives rise to a population and a chain of fermentation processes when the plant material is collected and prepared for fermentation.

Currently, the available information about the use of medicinal plants as a source of LAB and their subsequent potential application as components to form starters for fermented milks is scarce (Venugopalan et al., 2010). There are no data in the scientific literature about microbial presence of different types of bacteria, in particular LAB, isolated from representatives of the genus Salvia. Different types of this medicinal plant are grown and used worldwide as a spice in cooking and in traditional and folk medicine because of their antibacterial, antioxidant, antiinflammatory and analgesic properties (Ibrahim et al., 2012). A recent new direction in scientific research is related to: obtaining bioactive or biogenic substances extracted from different plants or synthesized during food fermentation; subsequent creation of novel foods (defined as healthy and functional) by additional introduction into their technological schemes of exogenous functional components or use of microorganisms, producers of biogenic substances, as well as microorganisms with probiotic characteristics (Gobbetti et al., 2010).

The aim of this study was to prove that representatives of the genus Salvia are alternative ecological niche for isolation and identification of LAB with metabolic activities and characteristics, providing subsequent potential possibility for in situ cultivation in milk when producing fermented dairy products.

\section{MATERIAL AND METHODS}

\section{Collection of plant samples}

The plant material from various representatives of the genus Salvia was collected from six regions in Bulgaria and one region in Germany as follows: $S$. scabiosifolia Lam. - Rousse region (area "Bazkite", town of Byala) and from Sofia region (experimental field of the Institute of Biodiversity and Ecosystem Research (IBER) - BAS); S. ringens Sibth. \& Sm. - Sofia region (IBER - BAS), Shumen plateau (Osmar village), Varna region ("Taushan Tepe", Nevsha village); S. officinalis L. - Sofia region (IBER - BAS) and Eastern Rhodopes ("Dayma" region, town of Kroumovgrad and "Luda reka" river, town of Ivaylovgrad); S. tomentosa Mill. - Sofia region (IBER - BAS); S. blepharophylla Brandegee ex Epling - Botanical garden of the Technical University in Dresden, Germany. The samples were taken aseptically, in sterile tubes, and transported under refrigeration to the laboratory for analyses.

Isolation of lactic acid bacteria 
Individual parts (flower, leaf and stem) of each plant species were carefully washed in sterile water, then transferred to test tubes with sterile $10 \%$ RSM (Reconstituted Skim Milk) (HiMedia, India) and incubated at temperatures - 30 ${ }^{\circ} \mathrm{C}$ and $37{ }^{\circ} \mathrm{C}$ for time period defined from the moment of coagulation of milk for the relevant sample. After visual assessment of milk coagulation, gas formation and non-specific odour, the samples were selected for subsequent transfer to M17 broth (Merck, Germany, Darmstadt) and MRS broth (Merck, Germany, Darmstadt), with added $100 \mu \mathrm{g} / \mathrm{mL}$ of cycloheximide (Sigma-Aldrich, USA, St. Louis) (Hartnett et al., 2002) in order to prevent fungal growth and to select LAB. Selected samples were cultured under anaerobic conditions in anaerobic jars with Anaerocult A mini system (Merck, Darmstadt, Germany) for $72 \mathrm{~h}$ at the above-mentioned temperatures. Broth cultures subjected to serial decimal dilution with $0.85 \%$ (w/v) sterilized $\mathrm{NaCl}$ solution were plated by spreading 0.1 $\mathrm{mL}$ on MRS agar (Merck, Germany, Darmstadt) and M17 agar (Merck, Germany, Darmstadt) plates. The plates were incubated under anaerobic conditions at $30{ }^{\circ} \mathrm{C}$ and $37{ }^{\circ} \mathrm{C}$ for $72-120 \mathrm{~h}$ to obtain LAB colonies. The colonies were selected randomly for purification by streaking again and subculturing on fresh agar plates of the isolation media. The purity of isolated single colonies was evaluated microscopically (Micros Pink MC50, Austria).

The abbreviation of the isolated lactic acid strains from the relevant plant samples includes: initials of the relevant plant species; an index indicating the location of the plant species or an initial of a nearby location to the region in question in Bulgaria, or abbreviated spelling of Germany. (For example SsfIB21: Ss - Salvia scabiosifolia, $\mathrm{f}$ - flower, IB - IBER - BAS, 21 - number of colony).

\section{Identification of lactic acid bacteria}

\section{Phenotypic and biochemical characteristics}

The initial study of bacterial isolates involved microscopic characterization of the morphology of cells (Micros Pink MC50, Austria) and colonies (shape, color and size) (CETI, Digi Steddy II, Belgium) and subsequent differentiating Gram staining. Biochemical tests (catalase test, oxidase test, reaction to indole) were carried out of selected Gram (+) isolates to establish their affiliation to the group of LAB.

Isolated presumptive LAB - Gram (+), catalase (-), indole (-), oxidase (-), were stored in M17 broth, containing $15 \%$ glycerol (Merck, Germany, Darmstadt) at $80{ }^{\circ} \mathrm{C}$ for use in subsequent examinations.

The presumptive $\mathrm{LAB}$ were tested for production of $\mathrm{CO}_{2}$ from glucose, by incubation for $72 \mathrm{~h}$ at $37^{\circ} \mathrm{C}$.

The lactic acid isomers produced from glucose in M17 broth ( $\mathrm{pH}$ 6.6) was determined enzymatically using $\mathrm{L}(+)$ and $\mathrm{D}(-)$ lactate dehydrogenase kit $\mathrm{K}$ DLATE 12/12 (Megazyme International Ireland Ltd), by incubation for $72 \mathrm{~h}$ at $37^{\circ} \mathrm{C}$.

The presumptive $\mathrm{LAB}$ that manifested high acid-producing activity were tested for growth in M17 broth (pH 6.6) at different temperatures $\left(4^{\circ} \mathrm{C}, 15^{\circ} \mathrm{C}, 30^{\circ} \mathrm{C}, 37\right.$ ${ }^{\circ} \mathrm{C}, 45{ }^{\circ} \mathrm{C}$ and $55^{\circ} \mathrm{C}$ ) for $72 \mathrm{~h}$, and for growth in $\mathrm{M} 17$ broth at different $\mathrm{pH}$ values (3.0, 5.0, 7.0, 8.0 and 9.6) at a temperature of $37{ }^{\circ} \mathrm{C}$ for $72 \mathrm{~h}$. The level of salt tolerance of presumptive LAB was determined after growth in M17 broth $(\mathrm{pH} 6.6)$ in the presence of various $\mathrm{NaCl}$ concentrations $(3.0 \%, 4.5 \%, 6.5 \%, 8.5 \%$ and $10.0 \%$ ), at $37^{\circ} \mathrm{C}$ for $72 \mathrm{~h}$.

For comparative characterization of the above-mentioned properties of presumptive LAB isolated from the genus Salvia, the latter were cultivated in parallel with LAB belonging to the collection of the laboratory and isolated from various dairy products or used in our previous studies - Lactococcus lactis ssp lactis biovar diacetylactis LD5 (L. diacetylactis LD5), Streptococcus thermophilus ST3 (S. thermophilus ST3), Lactococcus lactis ssp lactis LL3 (L. lactis LL3), Lactococcus lactis ssp cremoris LC1 (L. cremoris LC1), Enterococcus faecium EF4 (Ent. faecium EF4).

The preliminary identification of selected presumptive LAB were investigated using API 20 STREP (BioMerieux, Marcy-L`Etolie, France) galleries. The tests were conducted according to the instruction of the manufacturer and the results were read after incubation of strains at $37{ }^{\circ} \mathrm{C}$ for $48-72 \mathrm{~h}$.

\section{Genotypic characterization}

The isolates were grown anaerobically on M17 agar for $48 \mathrm{~h}$ at $37{ }^{\circ} \mathrm{C}$. Colonies were suspended in $1 \mathrm{~mL}$ Milli - Q water and centrifuged for $1 \mathrm{~min}$ at $12000 \mathrm{~g}$ Genomic DNA was isolated from a pellet by NucleoSpin ${ }^{\circledR}$ Soil Kit (MachereyNagel GmbH \& Co. KG, Düren, Germany), following the instruction of the manufacturer. The concentration of the resultant genomic DNA was measured by NanoDrop 2000 Spectrophotometer (Thermo Fisher Scientific, USA).

Fragments of the $16 \mathrm{~S}$ ribosomal gene were amplified, using universal primers 27F (5'-AGAGTTTGATCCTGGCTCAG-3') and 1492R (5' TACGGTTACCTTGTTACGACTT-3'). Each PCR mixture (50 $\mu \mathrm{L})$ contained a reaction mix of $25 \mu \mathrm{L}$ HotStarTaq Plus Master Mix Kit, 2x (Qiagen GmbH Germany), $1 \mu \mathrm{L}$ of each primer $(10 \mu \mathrm{M})$ and $100 \mathrm{ng}$ of DNA template and autoclaved Milli - $\mathrm{Q}$ water. The amplification was performed in Mastercycler $\mathbb{}$ pro (Eppendorf, NY, USA), including initial denaturation at $95{ }^{\circ} \mathrm{C}$ for $1 \mathrm{~min}$ followed by 33 cycles of denaturation at $95{ }^{\circ} \mathrm{C}$ for $15 \mathrm{~s}$, annealing at $50{ }^{\circ} \mathrm{C}$ for 30 s, elongation at $72{ }^{\circ} \mathrm{C}$ for $100 \mathrm{~s}$, and a final extension for $3 \mathrm{~min}$ at $72{ }^{\circ} \mathrm{C}$. The amplified product was cooled at $4{ }^{\circ} \mathrm{C}$. The PCR products (about $1500 \mathrm{bp}$ ) were analyzed by $1 \%(\mathrm{w} / \mathrm{v})$ agarose gel electrophoresis in 1xTAE buffer (stock 50xTAE: $242 \mathrm{~g} / \mathrm{L}$ Tris base, $57.1 \mathrm{~mL} / \mathrm{L}$ acetic acid, $100 \mathrm{~mL}$ 0.5M EDTA, pH 8.5 ) at $80 \mathrm{~V}$. The staining was performed in GelRed (Biotium, USA) fluorescent dye $(0.05 \mu \mathrm{g} / \mathrm{mL})$. The bands were visualized under ULTima 10SI (Hoefer Inc. USA). The sizes of DNA fragments were estimated using a standard $100 \mathrm{bp}$ DNA ladder (Invitrogen, USA). The PCR products were purified using NucleoSpin ${ }^{\circledR}$ Gel and PCR Clean-up (Macherey-Nagel GmbH \& Co. KG, Düren, Germany) according to the manufacturer's instructions.

The sequencing was performed in Eurofins MWG Operon (Germany). The sequence assembly was performed by using software BioEdit. The sequence similarity was evaluated by searching the homology in NCBI database, using BLAST. The results obtained were used to identify isolates to genus or species level. Phylogenetic tree were constructed, using Mega 4.1 software.

\section{Statistical analyses}

Data represent the mean values of three independent experiments. The errors of experimental data from the mean values were expressed as standard deviations using Microsoft Excel 2010 program and illustrated as error bars.

\section{RESULTS AND DISCUSSION}

\section{Isolation and obtaining bacterial isolates from Salvia species and their preliminary identification}

As a result of large-scale screening of 800 microbial isolates (derived from flower, leaf or stem of the 5 types of Salvia - S. Officinalis L., S. ringens Sibth. \& Sm., S. Blepharophylla Brandegee ex Epling, S. scabiosifolia Lam., S. tomentosa Mill.), based on visual assessment for milk coagulation, gas formation and nonspecific odour, 124 microbial isolates were selected, which is $15.5 \%$. After subsequent multiple transfer and growth in selective media, 460 single bacteria colonies were isolated. They were identified by classical techniques to prove their phenotypic characteristic and their respective affiliation to the group of LAB. The data from the required and confirmatory tests established that 12.2\% (56 single colonies) showed phenotypic identity with the group of LAB. They were Grampositive, catalase-negative, oxidase-negative and indole-negative. The flowers of the plant turned out to be the most favorite part for habitation of LAB (27 single colonies), followed by the leaves (15 colonies) and the stem ( 9 colonies) Lactobacteria were not isolated only from the species $S$. tomentosa Mill., and the highest number (25 colonies) were isolated from $S$. ringens Sibth. \& Sm. LAB were not isolated from $S$. officinalis $\mathrm{L}$. from the areas in the Eastern Rhodopes.

The presumptive LAB were morphologically defined only as cocci (arranged as a single cell, in pairs, in short or long chains) with a cell size from $0.3 \mu \mathrm{m}$ to 2.0 $\mu \mathrm{m}$. The relevant colonies are shiny, with a wide variety of colors (white, light beige and yellow), shape (circular - convex or flat, with entire or undulate margins) and size (from $1.1 \mathrm{~mm}$ to $3.1 \mathrm{~mm}$ ).

Each plant species provides unique growth conditions for different types of lactobacteria. Michaylova et al. (2007) have discovered that plant species Calendula officinalis, Capsella bursapastoris, Chrysanthemum, Cichorium intybus, Colchicum, Cornus mas, Galantus nivalis, Dianthus, Hedera, Nerium oleander, Plantago lanceolata, Prunus spinosa, Rosa and Tropaeolum are suitable sources for isolating cocci, and the species Calendula officinalis, Cornus mas, Galantus nivalis and Prunus spinosa for isolation of both cocci and rods From naturally fermented herbs used in traditional Herby Cheese in Turkey predominantly lactobacilli $(76.2 \%)$ vs $23.8 \%$ cocci were isolated (Cakir, 2010), and only rods were isolated from the herbal surface of Phyllanthus niruri (Venugopalan et al., 2010). Cocci and rods were isolated from the surface of Polygonum minus leaves, a Malaysian local herb (in a ratio 2:1) (Baradaran $\boldsymbol{e}$ al., 2012) and from different plants (Clover, Grass, Dandelion, Lilac flowers, Chestnut flowers, Hapatica flowers, Coltsfoot flowers and Rowan leaves) (Magnusson et al., 2003). Cocci were isolated from twenty grass varieties and vegetables (Alemayehu et al., 2014).

Regarding the ability of the isolated lactobacteria to produce $\mathrm{CO}_{2}$ from glucose, all tested isolates showed absence of such metabolic activity and hence they were referred to the group of homofermentative LAB.

Determination of isomeric forms of produced lactic acid, degree of halotolerance, and temperature and $\mathrm{pH}$ ranges for growth of bacteria

A significant characteristic of LAB intended for the dairy industry is their acidproducing activity, i.e. production of lactic acid (LA) during their homofermentative or heterofermentative metabolism. In this regard, LA production was studied and isomeric forms were determined during the homofermentative metabolism of presumptive LAB isolated from Salvia. The data for isomeric forms of LA produced by plant lactobacteria showed that $88.2 \%$ synthesize $\mathrm{L}(+)-\mathrm{LA}$, and $11.8 \% \mathrm{D}(-) / \mathrm{L}(+)-\mathrm{LA}$ (Fig 1A, B). Moreover, in the isolates producing both isomeric forms of LA the presence of $\mathrm{L}(+)-\mathrm{LA}$ is dominant. There were no representatives producing only $\mathrm{D}(-)$-LA. The highest activity of LA synthesis was observed in the isolates obtained from $S$ 
blepharophylla Brandegee ex Epling, with attained maximum concentration of $10.01 \mathrm{~g} / \mathrm{L}$ and $15.56 \mathrm{~g} / \mathrm{L}$ (Fig 1A). One half of the S. scabiosifolia Lam. isolates also showed a high acid-producing activity, with LA concentration in the range of $7.74 \mathrm{~g} / \mathrm{L}-10.29 \mathrm{~g} / \mathrm{L}$ (Fig 1A). Relatively lower concentrations of LA (about $4.00 \mathrm{~g} / \mathrm{L}-5.00 \mathrm{~g} / \mathrm{L}$ ) were found in S. ringens Sibth. \& Sm. isolates (Fig 1B).
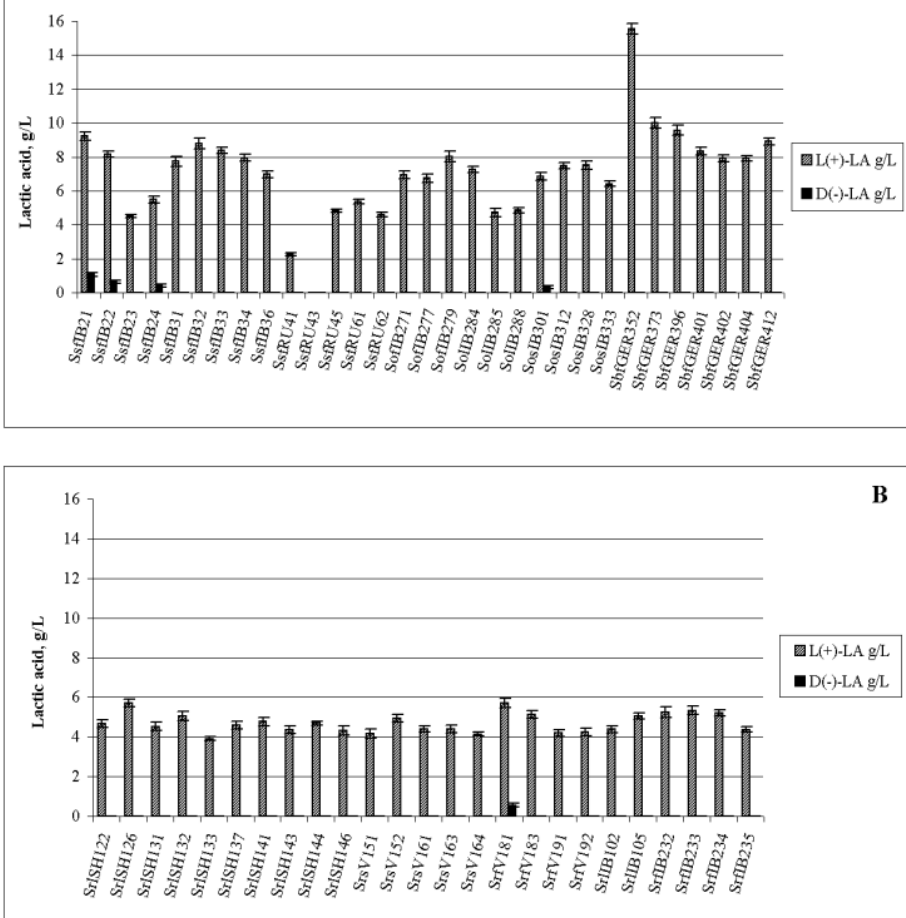

Figure 1 Isomeric forms of lactic acid produced by lactic acid bacteria, isolated from Salvia species: A - S.scabiosifolia Lam. (Ss), S. officinalis L. (So), S. blepharophylla Brandegee ex Epling (Sb); B - S.ringens Sibth. \& Sm. (Sr): $\mathbb{Z}$. L(+)-lactic acid; - D(-)-lactic acid

The observed concentrations of LA produced by selected LAB of plant origin are comparable to those produced by lactobacteria isolated from dairy products $-L$ diacetylactis LD5 - $10.00 \mathrm{~g} \mathrm{~L}(+)-\mathrm{LA} / \mathrm{L}$, L. lactis LL3 - $8.08 \mathrm{~g} \mathrm{~L}(+)-\mathrm{LA} / \mathrm{L}, L$. cremoris LC1 - $7.47 \mathrm{~g} \mathrm{~L}(+)-\mathrm{LA} / \mathrm{L}$, S. thermophilus ST3 - $9.39 \mathrm{~g} \mathrm{~L}(+)-\mathrm{LA} / \mathrm{L}$, Ent. faecium $\mathrm{EF} 4$ - $6.85 \mathrm{~g} \mathrm{~L}(+)-\mathrm{LA} / \mathrm{L}$ (Fig 2).

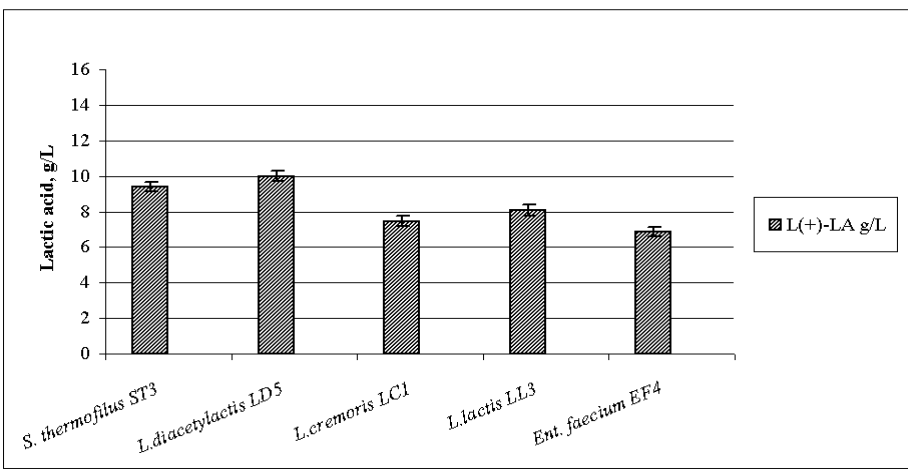

Figure 2 Isomeric forms of lactic acid produced by lactic acid bacteria, isolated from dairy products: $\mathbb{Z}$ - L(+)-lactic acid

Similar results were reported by Kimoto et al. (2004), who obtained 20 raw grass bacterial isolates, 'napiergrass' in Japanese, thereafter morphologically defined and tested as homofermentative cocci, producing only L(+)-LA. Kostinek $\boldsymbol{e t}$ al. (2007) have also isolated homofermentative cocci from fermented cassava, producing only $\mathrm{L}(+)$-LA. Other researchers have isolated homofermentative cocci, producing only $\mathrm{D}(-) / \mathrm{L}(+)$-LA, from traditionally fermented vegetable products of the Eastern Himalayas (Tamang $\boldsymbol{e t}$ al., 2005) and from fermented tea leaves (miang) in Thailand (Tanasupawat et al., 2007), respectively. Unlike our data, heterofermentative cocci producing only D (-)-LA have also been isolated from the above plant sources with the exception of fermented tea. (Tamang $\boldsymbol{e}$ al., 2005; Kostinek et al., 2007). Besides determination of isomeric forms of LA synthesized by presumptive lactobacteria, some authors have also reported data on LA concentrations as an element of their pre-identification. In this regard, the results reported by Cock and De Stouvenel (2006) are of interest, who, out of 20 selected bacterial isolates obtained from sugar molasses leaves, selected only one strain (with index CC 85-92), with a high potential for synthesis of L(+)-LA $\left(12.4 \mathrm{~g} / \mathrm{L}\right.$ and $13.7 \mathrm{~g} / \mathrm{L}$, at cultivation temperatures $36{ }^{\circ} \mathrm{C}$ and $32{ }^{\circ} \mathrm{C}$, respectively). These data are comparable with the results obtained for the isolates in this study (Fig 1A, B). With this strain, cultivated in parameters suitable for targeted synthesis of LA, the authors reached the maximum yield of $35.0 \mathrm{~g} / \mathrm{L}$. Growth parameters (temperature, $\mathrm{pH}$ and presence of $\mathrm{NaCl}$ ) of $\mathrm{LAB}$ are essential physiological parameters for the phenotypic characteristic of the relevant type, showing aspects for their subsequent application in various technological schemes. Almost all isolates showed very good growth in a wide temperature range $\left(15^{\circ} \mathrm{C}-45^{\circ} \mathrm{C}\right)$, good and weak growth at $4{ }^{\circ} \mathrm{C}$ and absence of growth at $55^{\circ} \mathrm{C}$ (Table 1). The $\mathrm{pH}$ range for growth of most isolates was also extended, i.e. very good growth was obtained in the range of $7.0-9.6$, good growth at $\mathrm{pH} 5.0$, and absence of growth at $\mathrm{pH}$ value of 3.0 (Table 1). Data for a wide temperature range of growth $\left(15{ }^{\circ} \mathrm{C}-45^{\circ} \mathrm{C}\right)$ and $\left(10{ }^{\circ} \mathrm{C}-45^{\circ} \mathrm{C}\right)$ were reported by Tanasupawat et al. (2007) and Baradaran et al. (2012) for lactococci isolated from fermented tea leaves and from the herb Polygonum minus, respectively. The same authors established that the isolates studied by them grow well also within a $\mathrm{pH}$ range of $3.0-7.0$ and $4.0-8.5$, which is in accordance with the results reported by Tamang et al. (2005) for lactococci of other plant origin (fermented vegetable products). Alemayehu et al. (2014) proved good growth at $\mathrm{pH} 9.5$ of lactococci isolated from grass varieties and vegetables. The studied plant isolates showed better growth characteristics in a broader temperature and $\mathrm{pH}$ range in comparison to those of LAB of dairy origin (Table 1). A similar trend was recorded for their halotolerance (Table 1). The major part of plant isolates showed very good growth in a medium containing $\mathrm{NaCl}$, at concentrations from $3.0 \%$ to $6.5 \%$. At $8.5 \%$ concentraction of $\mathrm{NaCl}$, about $1 / 2$ of the isolates showed good growth. $10 \% \mathrm{NaCl}$ concentration proved to be inhibitory for nearly all isolates. Tamang et al. (2005), Baradaran et al. (2012) and Alemayehu et al. (2014) established a high level of halotolerance (growth in the presence of $10 \%$ $\mathrm{NaCl}$ and $6.5 \% \mathrm{NaCl}$ ), but Kimoto et al. (2004) and Tanasupawat et al. (2007) found a lower level (growth in the presence of $4.0 \% \mathrm{NaCl}$ ) for lactococci of different plant origin.

\section{Identification of lactic acid bacteria by PCR and constructing of a phylogenetic tree}

Phenotyping of LAB using morphological, physiological and biochemical (API 20 STREP) characteristics identified representatives of several species belonging to the genera Lactococcus and Enterococcus with a similarity of about $60 \%$ and $80 \%$, respectively. The identification system used did not give $100 \%$ accuracy of identity.

Genotyping is known to give a surer identity of microorganisms. Basically genotype-based methods such as $16 \mathrm{~S}$ rDNA sequencing represent a successful addition to phenotypic methods for precise identification of lactobacteria isolated from certain microbial communities (Kostinek et al., 2007; Tanasupawat et al., 2007; Chen et al., 2010; Kpikpi et al., 2010; Baradaran et al., 2012; Venturi et al., 2012; Alemayehu et al., 2014). Although LAB are widespread, each plant habitat is characterized by a specific microbocenosis, having a different biological activity. The isolated DNA from phenotypically characterized bacterial isolates was used as a matrix for PCR amplification of $16 \mathrm{~S}$ rDNA genes. The combination of PCR amplification of $16 \mathrm{~S}$ rDNA genes, sequencing of the resulting PCR products and the subsequent comparison of their sequences with the ones existing in the database NCBI allowed a precise identification of the presumed LAB to a species level, as well as their phylogenetic grouping. The majority $(69.0 \%)$ of isolates analyzed showed affiliation to the genus Enterococcus. Full compliance of phenotypic characteristic and the results of PCR analysis with a nearly $100 \%$ homology of the nucleotide sequence allowed us to relate the strains SofIB271, SofIB279, SofIB284, SofIB328 to the species Ent. faecium. The strains SsfIB21, SsfIB22, SsfIB32, SsfIB33, SsfIB34, SofIB277, SosIB301, SosIB312, SrsV161 are also related to the same species and demonstrated a high level of homology - 99\%. The strains SrlSH132, SrlSH141, SrlSH144 demonstrated the same homology (99\%) as both species - Ent. casseliflavus and Ent. gallinarum, but the phenotypic difference between the two species regarding the color of the colony, yellow and white, respectively, determined the affiliation of the isolates to Ent. casseliflavus. Strains SsfIB24, SrsV151, SolIB288 were identified as Ent. mundtii with 99\% homology to the nucleotide sequence and SolIB285 - 100\%.

A minor part, (20.7\% and $10.3 \%)$ of the isolates analyzed were identified as representatives of the genus Lactococcus and the genus Streptococcus, respectively. A high level of similarity $(99.0 \%)$ with $L$. lactis subsp lactis was recorded for the strains SsfRU61, SsfRU62, SrfV183, SrfIB232, SrfIB233, and for the strain SrfV181 - 100\% similarity. A 99\% homology of the nucleotide sequence allowed us to relate strains SbfGER352, SbfGER373, SbfGER401 to the species $S$. thermophilus.

Evidence of genotyped representatives of the species of the genera Enterococcus, Lactococcus, Streptococcus established in this study in isolates of different origin have also been reported by other authors (Hartnett et al., 2002; Kimoto et 
al., 2004; Cock and De Stouvenel, 2006; Nomura et al., 2006; Michaylova et al., 2007; Baradaran et al., 2012). Hartnett et al. (2002) reported about identified Ent. faecium and L. lactis in isolates from raw barley, and in isolates from sorghum were defined the species Ent. mundtii and the species Ent. faecalis - undetected in studied by us plant isolates from Salvia. The species L. lactis was isolated and identified from a type of Japanese raw grass (napiergrass) (Kimoto et al., 2004; Nomura et al., 2006) and from the leaves of sugar beet (Cock and De Stouvenel, 2006). Except L. lactis, Baradaran et al. (2012) Pediococcus pentosaceus and Lactobacillus curvatus were defined in isolates of Polygonum minus (a Malaysian herb). S. thermophilus has been isolated from the leaves of 14 different plant species, and in isolates from 4 plant species Lactobacillus bulgaricus has also been identified (Michaylova et al., 2007). L. lactis ssp lactis and L. lactis ssp cremoris (Alemayehu et al., 2014) were isolated from grass varieties and vegetables. The summarized data reveal that each of the studied plant habitat represents a separate ecological niche for growth of specific lactic acid microflora.

Based on data from conducted 16S rDNA gene sequence analysis, using computer program Mega 4.1, it was constructed a phylogenetic tree, which displays a high consistency regarding relationships between the studied strains (Fig 3). The phylogenetic tree shows the diversity of the isolated plant - derived lactic acid bacteria, belonging to genera Enterococcus, Streptococcus and Lactococcus, as well as it displays the phylogenetic position of the isolates, divided into several clusters and sub-clusters. It also demonstrates nice patterns of the isolates based on geographical regions and plant parts, where they were isolated from

Table 1 Effect of temperature, $\mathrm{pH}$ and $\mathrm{NaCl}$ concentration on survival of bacterial isolates and LAB of dairy origin

\begin{tabular}{|c|c|c|c|c|c|c|c|c|c|c|c|c|c|c|c|c|}
\hline \multirow{2}{*}{ Isolates } & \multicolumn{6}{|c|}{ Temperature $\left({ }^{\circ} \mathrm{C}\right)$} & \multicolumn{5}{|c|}{$\mathbf{p H}$} & \multicolumn{5}{|c|}{$\mathrm{NaCl}(\%)$} \\
\hline & 4 & 15 & 30 & 37 & 45 & 55 & 3.0 & $\mathbf{5 . 0}$ & 7.0 & 8.0 & 9.6 & 3.0 & 4.5 & 6.5 & 8.5 & 10 \\
\hline SsfIB21 & + & ++ & ++ & ++ & ++ & - & - & + & ++ & ++ & ++ & ++ & ++ & ++ & + & - \\
\hline SsfIB22 & + & ++ & ++ & ++ & ++ & - & - & + & ++ & ++ & ++ & ++ & ++ & ++ & + & $t^{\mathrm{w}}$ \\
\hline SsfIB24 & + & ++ & ++ & ++ & ++ & - & - & + & ++ & ++ & ++ & ++ & ++ & ++ & + & - \\
\hline SsfIB32 & + & ++ & ++ & ++ & ++ & - & - & + & ++ & ++ & ++ & ++ & ++ & ++ & + & - \\
\hline SsfIB33 & + & ++ & ++ & ++ & ++ & - & - & + & ++ & ++ & ++ & ++ & ++ & ++ & $+{ }^{\mathrm{w}}$ & $t^{\mathrm{w}}$ \\
\hline SsfIB34 & + & ++ & ++ & ++ & ++ & - & - & + & ++ & ++ & + & ++ & ++ & ++ & + & - \\
\hline SsfRU61 & + & ++ & ++ & ++ & - & - & - & + & ++ & ++ & + & ++ & + & - & - & - \\
\hline SsfRU62 & + & ++ & ++ & ++ & - & - & - & + & ++ & + & + & ++ & + & - & - & - \\
\hline SrlSH132 & $+{ }^{\mathrm{w}}$ & + & ++ & ++ & ++ & - & - & + & ++ & ++ & ++ & + & + & + & +- & - \\
\hline SrlSH141 & + & ++ & ++ & ++ & ++ & - & - & + & ++ & ++ & ++ & ++ & ++ & + & - & - \\
\hline SrlSH144 & + & ++ & ++ & ++ & ++ & - & - & + & ++ & ++ & ++ & + & + & $+{ }^{\mathrm{w}}$ & $+{ }^{\mathrm{w}}$ & - \\
\hline SrsV151 & + & ++ & ++ & ++ & ++ & - & - & ++ & ++ & ++ & ++ & ++ & ++ & ++ & + & + \\
\hline SrsV161 & + & ++ & ++ & ++ & ++ & - & - & + & ++ & ++ & ++ & ++ & ++ & ++ & + & + \\
\hline SrfV181 & $+{ }^{\mathrm{w}}$ & + & ++ & ++ & $+{ }^{\mathrm{w}}$ & - & - & + & ++ & ++ & + & + & + & - & - & - \\
\hline SrfV183 & + & ++ & ++ & ++ & $+{ }^{\mathrm{w}}$ & - & - & + & ++ & ++ & ++ & ++ & ++ & + & - & - \\
\hline SrfIB232 & + & + & ++ & ++ & $+^{\mathrm{w}}$ & - & - & + & ++ & ++ & + & ++ & ++ & + & - & - \\
\hline SrfIB233 & $+{ }^{\mathrm{w}}$ & + & ++ & ++ & $+^{\mathrm{w}}$ & - & - & + & ++ & + & + & ++ & + & + & + & - \\
\hline SofIB271 & + & ++ & ++ & ++ & ++ & - & - & + & ++ & ++ & ++ & ++ & ++ & ++ & + & - \\
\hline SofIB277 & + & ++ & ++ & ++ & ++ & - & - & + & ++ & ++ & ++ & ++ & ++ & ++ & + & - \\
\hline SofIB279 & + & ++ & ++ & ++ & ++ & - & - & + & ++ & ++ & ++ & ++ & ++ & ++ & ++ & $t^{w}$ \\
\hline SolIB284 & + & ++ & ++ & ++ & ++ & - & - & + & ++ & ++ & + & ++ & ++ & ++ & + & - \\
\hline SolIB285 & + & ++ & ++ & ++ & ++ & - & - & + & ++ & ++ & ++ & ++ & ++ & ++ & + & - \\
\hline SolIB288 & + & ++ & ++ & ++ & ++ & - & - & + & ++ & ++ & + & ++ & ++ & ++ & + & - \\
\hline SosIB301 & + & ++ & ++ & ++ & ++ & - & - & + & ++ & ++ & + & ++ & ++ & ++ & + & $t^{w}$ \\
\hline SosIB312 & + & ++ & ++ & ++ & ++ & - & - & + & ++ & ++ & ++ & ++ & ++ & ++ & + & $+^{\mathrm{w}}$ \\
\hline SosIB328 & + & ++ & ++ & ++ & ++ & - & - & + & ++ & ++ & ++ & ++ & ++ & ++ & ++ & - \\
\hline SbfGER352 & $+{ }^{\mathrm{w}}$ & $+{ }^{\mathrm{w}}$ & ++ & ++ & ++ & - & - & + & ++ & ++ & + & - & - & - & - & - \\
\hline SbfGER373 & $+{ }^{\mathrm{w}}$ & $++^{\mathrm{w}}$ & ++ & ++ & ++ & - & - & + & ++ & ++ & + & - & - & - & - & - \\
\hline SbfGER401 & $+{ }^{\mathrm{w}}$ & $++^{\mathrm{w}}$ & ++ & ++ & ++ & - & - & + & ++ & + & + & - & - & - & - & - \\
\hline L.lactis $\mathbf{L L 3}$ & $+{ }^{\mathrm{w}}$ & $+{ }^{\mathrm{w}}$ & ++ & ++ & - & - & - & + & ++ & + & $+^{\mathrm{w}}$ & ++ & + & $+{ }^{\mathrm{w}}$ & - & - \\
\hline L.cremoris LC1 & - & $++^{\mathrm{w}}$ & ++ & ++ & - & - & - & + & ++ & + & - & + & - & - & - & - \\
\hline L.diacetylactis LD5 & $+{ }^{\mathrm{w}}$ & + & ++ & ++ & - & - & - & + & ++ & + & $+{ }^{\mathrm{w}}$ & + & + & $+{ }^{\mathrm{w}}$ & - & - \\
\hline S.thermophilus ST3 & $+{ }^{\mathrm{w}}$ & $+{ }^{\mathrm{w}}$ & ++ & ++ & ++ & $+^{\mathrm{w}}$ & - & + & ++ & + & $+^{\mathrm{w}}$ & $t^{\mathrm{w}}$ & $+^{\mathrm{w}}$ & $+{ }^{\mathrm{w}}$ & - & - \\
\hline E.faecium EF4 & + & ++ & ++ & ++ & ++ & $+^{\mathrm{w}}$ & - & + & ++ & ++ & ++ & ++ & ++ & + & + & $+t^{w}$ \\
\hline
\end{tabular}

Growth: ++ very good; + good; - no; ${ }^{\text {w }}$ weak; 


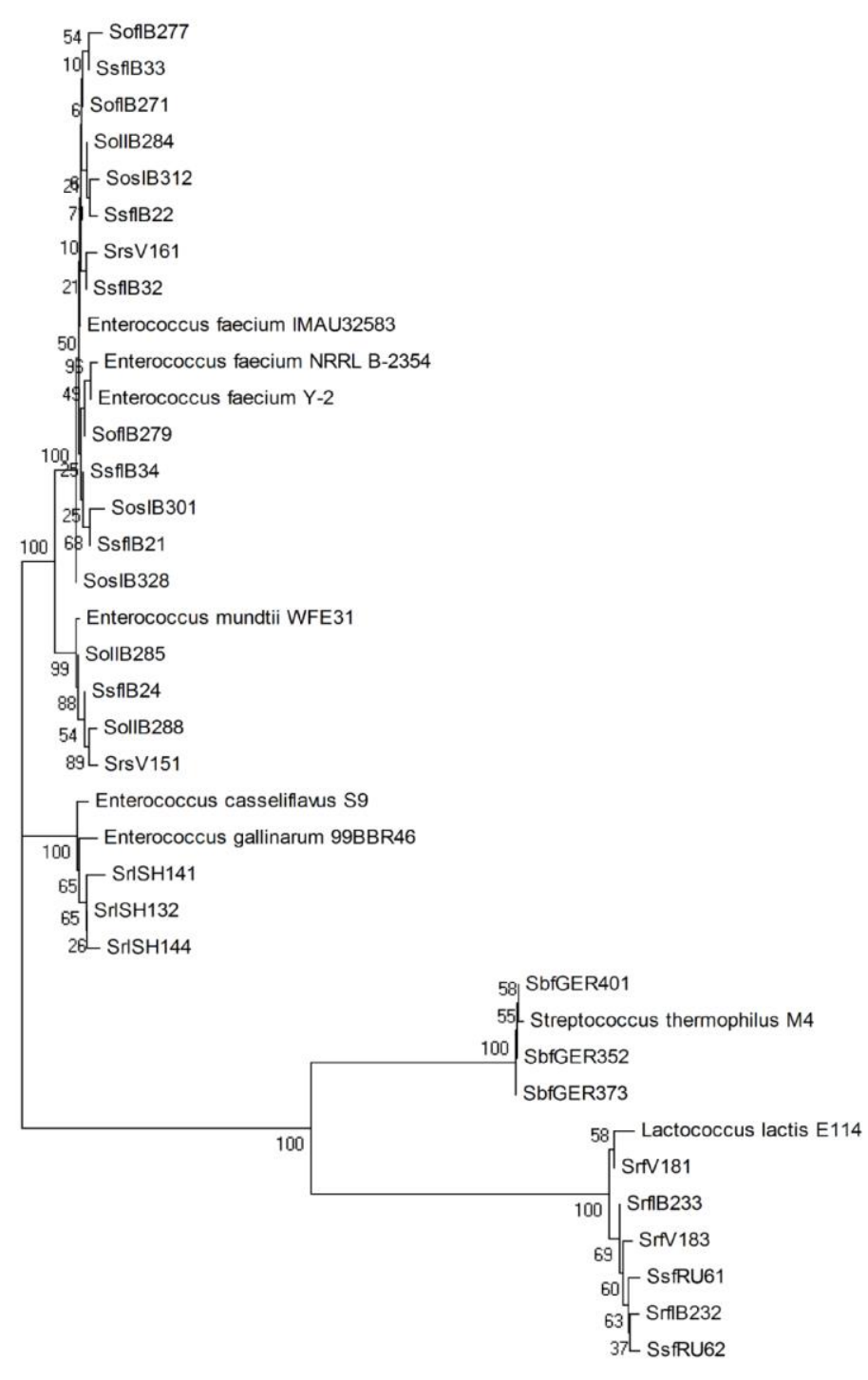

$\stackrel{5}{0.01}$

Figure 3 Phylogenetic tree based on the 16S rDNA gene sequences, of identified isolates from medicinal plants (representatives of genus Salvia), determined using the neighbor-joining method

\section{CONCLUSION}

The results of this study show that representatives of the genus Salvia ( $S$ officinalis, S. ringens Sibth. \& Sm., S. Blepharophylla Brandegee ex Epling, $S$. scabiosifolia Lam.) are appropriate ecological niches for isolation of various types of lactococci, unlike the species S. tomentosa Mill. The better growth characteristics of the isolated and identified lactococci (wide $\mathrm{pH}$ and temperature range) as well as their higher acid-producing activity, comparable to LAB of dairy origin, are an advantage and a good prerequisite for in situ cultivation in milk and subsequent formation of starter cultures for new fermented diary products.

\section{REFERENCES}

ABEGAZ, K. 2014. Isolation, characterization and identification of lactic acid bacteria involved in traditional fermentation of borde, an Ethiopian cereal beverage. International Journal of Food and Nutrition Sciences, 1, 7-15.

ALEMAYEHU, D., HANNON, J.A., MCAULIFFE, O., ROSS, R.P. 2014 Characterization of plant-derived lactococci on the basis of their volatile compounds profile when grown in milk. International Journal of Food Microbiology, 172, 57-61.

http://dx.doi.org/10.1016/j.ijfoodmicro.2013.11.024

BARADARAN, A., FOO, H.L., SIEO, C.C., RAHIM R.A. 2012. Isolation, identification and characterization of lactic acid bacteria from Polygonum minus. Romanian Biotechnological Letters, 17, 7245-7252.
CAKIR, I. 2010. Antibacterial and antifungal activities of some lactic acid bacteria isolated from naturally fermented herbs. Journal of Food, Agriculture \& Environment, 8, 223-226.

CHEN, Y.-S,, WU, H., YANAGIDA, F. 2010. Isolation and characteristics of lactic acid bacteria isolated from ripe mulberries in Taiwan. Brazilian Journal of Microbiology, 41, 916-921.

http://dx.doi.org/10.1590/s1517-83822010000400010

COCK, L.S, DE STOUVENEL, A.R. 2006. Lactic acid production by a strain of Lactococcus lactis subs lactis isolated from sugar cane plants. Electronic Journal of Biotechnology, 9, 40-45.

http://dx.doi.org/10.2225/vol9-issue1-fulltext-10

DI CAGNO, R., RIZZELLO, C.G., GAGLIARDI, F., RICCIUTI, P., NDAGIJIMANA, M., FRANCAVILLA, R., GUERZONI, M.E., CRECCHIO, C., GOBBETTI, M., DE ANGELIS, M. 2009. Different Fecal Microbiotas and Volatile Organic Compounds in Treated and Untreated Children with Celiac Disease. Applied and Environmental Microbiology, 75, 3963-3971.

http://dx.doi.org/10.1128/aem.02793-08

EMERENINI, E.C., AFOLABI, O.R., OKOLIE, P.I., AKINTOKUN, A.K. 2013 Isolation and molecular characterization of lactic acid bacteria isolated from fresh fruits and vegetables using nested PCR analysis. British Microbiology Research Journal, 3, 368-377.

http://dx.doi.org/10.9734/bmrj/2013/2520

FHOULA I., NAJJARI A., TURKI Y., JABALLAH S., BOUDABOUS A., AND OUZARI H. 2013. Diversity and antimicrobial properties of lactic acid bacteria isolated from rhizosphere of olive trees and desert truffles of Tunisia. BioMed Research International. 2013: 405708.

http://dx.doi.org/10.1155/2013/405708

GAD, G.F.M., ABDEL-HAMID, A.M., FARAG, Z.S.H. 2014. Antibiotic resistance in lactic acid bacteria isolated from some pharmaceutical and dairy products. Brazilian Journal of Microbiology, 45, 25-33. http://dx.doi.org/10.1590/s1517-83822014000100005

GOBBETTI, M., DI CAGNO, R., DE ANGELIS, M. 2010. Functional microorganisms for functional food quality. Critical Reviews in Food Science and Nutrition, 50, 716-727.

http://dx.doi.org/10.1080/10408398.2010.499770

GULEY, Z., UYSAL, H.R., KILIC, S. 2014/15. Lactic acid bacteria flora of Konya Kuflu Cheese: a traditional cheese from Konya province in Turkey. Journal of Microbiology, Biotechnology and Food Sciences, 4, 238-242. http://dx.doi.org/10.15414/jmbfs.2014-15.4.3.238-242

HARTNETT, D. J., VAUGHAN, A., VAN SINDEREN, D. 2002. Antimicrobialproducing lactic acid bacteria isolated from raw barley and sorghum. Journal of the Institute of Brewing, 108, 169-177.

http://dx.doi.org/10.1002/j.2050-0416.2002.tb00537.x

IBRAHIM, T. A. 2012. Chemical composition and biological activity of extracts from Salvia bicolor Desf. growing in Egypt. Molecules, 17, 11315-11334. http://dx.doi.org/10.3390/molecules 171011315

KIMOTO, H, NOMURA, M., KOBAYASHI, M., OKAMOTO, T., OHMOMO, S. 2004. Identification and probiotic characteristics of Lactococcus strains from plant materials. Japan Agricultural Research Quarterly, 38, 111-117.

http://dx.doi.org/10.6090/jarq.38.111

KOSTINEK, M., SPECHT, I., EDWARD, V.A., PINTO, C., EGOUNLETY, M. SOSSA, C., MBUGUA, S., DORTU, C., THONART, P., TALJAARD, L., MENGU, M., FRANZ, C.M.A.P., HOLZAPFEL, W.H. 2007. Characterisation and biochemical properties of predominant lactic acid bacteria from fermenting cassava for selection as starter cultures. International Journal of Food Microbiology, 114, 342-351.

http://dx.doi.org/10.1016/j.ijfoodmicro.2006.09.029

KPIKPI, E.N., GLOVER, R.L.K., DZOGBEFIA, V.P., NIELSEN, D.S. JAKOBSEN, M. 2010. Isolation of lactic acid bacteria from kantong, a condiment produced from the fermentation of kapok (Ceiba pentandra) seeds and cassava (Manihot esculentum) flour. Report and Opinion, 2, 1-7.

MAGNUSSON, J., STRÖM, K., ROOS, S., SJÖGREN, J., SCHNÜRER, J. 2003. Broad and complex antifungal activity among environmental isolates of lactic acid bacteria. FEMS Microbiology Letters, 219, 129-135.

http://dx.doi.org/10.1016/s0378-1097(02)01207-7

MICHAYLOVA, M., MINKOVA, S., KIMURA, K., SASAKI, T., ISAWA, K 2007. Isolation and characterization of Lactobacillus delbrueckii ssp. bulgaricus and Streptococcus thermophilus from plants in Bulgaria. Federation of European Microbiological Societies Microbiology Letters, 269, 160-169.

http://dx.doi.org/10.1111/j.1574-6968.2007.00631.x

NGUYEN, T.H.K., DOAN, V.T.T., HA, L.D., NGUYEN, H.N. 2013. Molecular cloning, expression of minD gene from Lactobacillus acidophilus VTCC-B-871 and analyses to identify Lactobacillus rhamnosus PN04 from Vietnam Hottuynia cordata Thunb. Indian Journal of Microbiology, 53, 385-390.

http://dx.doi.org/10.1007/s12088-013-0384-1

NOMURA, M., KOBAYASHI, M., NARITA, T., KIMOTO-NIRA, H., OKAMOTO, T. 2006. Phenotypic and molecular characterization of Lactococcus lactis from milk and plants. Journal of Applied Microbiology, 101, 396-405. http://dx.doi.org/10.1111/j.1365-2672.2006.02949.x 
SIEZEN, R.J., STARRENBURG, M.J.C., BOEKHORST, J., RENCKENS B., MOLENAAR, D., VAN HYLCKAMA VLIEG, J.E.T. 2008. Genome-scale genotype-phenotype matching of two Lactococcus lactis isolates from plants identifies mechanisms of adaptation to the plant niche. Applied and Environmental Microbiology, 74, 424-436.

http://dx.doi.org/10.1128/aem.01850-07

TAMANG, J.P., TAMANG, B., SCHILLINGER, U., FRANZ, C.M., GORES, M., HOLZAPFEL, W.H. 2005. Identification of predominant lactic acid bacteria isolated from traditionally fermented vegetable products of the Eastern Himalayas. International Journal of Food Microbiology, 105, 347-356.

http://dx.doi.org/10.1016/j.ijfoodmicro.2005.04.024

TANASUPAWAT, S., PAKDEETO, A., THAWAI, C., YUKPHAN, P., OKADA, S. 2007; Identification of lactic acid bacteria from fermented tea leaves (miang) in Thailand and proposals of Lactobacillus thailandensis sp. nov., Lactobacillus camelliae sp. nov., and Pediococcus siamensis sp. nov. The Journal of General and Applied Microbiology, 53, 7-15.

http://dx.doi.org/10.2323/jgam.53.7

TRIAS, R., BAÑERAS, L., MONTESINOS, E., BADOSA, E. 2008. Lactic acid bacteria from fresh fruit and vegetables as biocontrol agents of phytopathogenic bacteria and fungi. International microbiology, 11, 231-236.

VENTURI, M., GUERRINI, S., GRANCHI, L., VINCENZINI, M. 2012. Typing of Lactobacillus sanfranciscensis isolates from traditional sourdoughs by combining conventional and multiplex RAPD-PCR profiles. International Journal of Food Microbiology, 156, 122-126.

http://dx.doi.org/10.1016/j.ijfoodmicro.2012.03.011

VENUGOPALAN, V., DINESH, M.S., GEETHA, K.S. 2010. Enhancement of antimicrobial potential of phyllanthus niruri by fermentation. Journal of Herbal Medicine and Toxicology, 4, 167-175. 